\title{
Assessment of growth and yield performance of rubber tree clones of the IAC $\mathbf{5 0 0}$ series
}

\author{
Paulo de Souza Gonçalves(1), Erivaldo José Scaloppi Júnior ${ }^{(2)}$, Maria Alice Martins ${ }^{(3)}$, \\ Rogério Manoel Biagi Moreno(3), Roberto Botelho Ferraz Branco(4) and Elaine Cristine Piffer Gonçalves ${ }^{(5)}$
}

\begin{abstract}
(1)Instituto Agronômico, Programa Seringueira, Caixa Postal 28, CEP 13020-970 Campinas, SP, Brazil. E-mail: paulog@iac.sp.gov.br (2) Agência Paulista de Tecnologia dos Agronegócios (APTA), Polo Regional Noroeste Paulista, Caixa Postal 61, CEP 15500-000 Votuporanga, SP, Brazil. E-mail: scaloppi@apta.sp.gov.br ${ }^{(3)}$ Embrapa Instrumentação Agropecuária, Caixa Postal 741, CEP $13560-970$ São Carlos, SP, Brazil. E-mail: mariaalice@cnpdia.embrapa.br, rogerio@cnpdia.embrapa.br ${ }^{(4)}$ APTA, Polo Regional Centro Leste, Caixa Postal 271, CEP 14001-970 Ribeirão Preto, SP, Brazil. E-mail: branco@apta.sp.gov.br ${ }^{(5)}$ APTA, Polo Regional Alta Mogiana, Caixa Postal 35, CEP 14770-000 Colina, SP, Brazil. E-mail: elainegoncalves@aptaregional.sp.gov.br
\end{abstract}

\begin{abstract}
The objective of this work was to evaluate the performance of 15 clones of the IAC 500 series of Hevea brasiliensis, developed at Instituto Agronômico (IAC), over a 12-year period, in the northwest region of São Paulo State, Brazil. The 15 new clones evaluated are primary clones obtained from selected ortets within half-sib progenies. The clone RRIM 600, of Malaysian origin, was used as the control. Dry rubber yield performance over a four-year period, mean girth at the tenth year, girth increment before and during tapping, thermal properties of the natural rubber produced and other characters of the laticiferous system were evaluated. Forty percent of the clones were superior in comparison to the control for yield. Clone IAC 500 recorded the highest yield $(66.81 \mathrm{~g}$ per tree per tapping) over four years of tapping, followed by IAC 502 (62.37 g per tree per tapping), whereas the control recorded $48.71 \mathrm{~g}$ per tree per tapping. All selected clones were vigorous in growth. The natural rubber from this IAC clones showed thermal stability up to $300^{\circ} \mathrm{C}$. No differences were observed in the thermal behavior of rubber among the IAC series and the RRIM 600 clones. The clones IAC 500, IAC 501, IAC 502, IAC 503 and IAC 506 are the more promising for small-scale plantations, due to growth and yield potential.
\end{abstract}

Index terms: Hevea brasiliensis, bark thickness, brown bast, vigor, yield.

\section{Avaliação do vigor e do desempenho da produção de clones de seringueira da série IAC $\mathbf{5 0 0}$}

Resumo - O objetivo deste trabalho foi avaliar o desempenho de 15 clones da série IAC 500 de Hevea brasiliensis, desenvolvidos pelo Instituto Agronômico (IAC), durante um período de 12 anos, na região noroeste do Estado de São Paulo. Os 15 novos clones avaliados são clones primários resultantes de ortetes selecionados dentro de progênies de meios-irmãos. O clone RRIM 600, de origem Malaia, foi usado como testemunha. Foram avaliados: desempenho da produção por um período de quatro anos, média do perímetro do caule no décimo ano, incremento anual do perímetro antes e durante a sangria, propriedades térmicas da borracha natural produzida e outros caracteres do sistema laticífero. Quarenta por cento dos clones foram superiores em produção, em comparação ao clone RRIM 600. O clone IAC 500 registrou a maior produção (66,81 g por árvore por sangria) em quatro anos de sangria, seguido pelo IAC 502 (62,37 g por árvore por sangria), enquanto o clone testemunha registrou $48,71 \mathrm{~g}$ por árvore por sangria. Todos os clones selecionados apresentaram crescimento vigoroso. As borrachas avaliadas apresentaram estabilidade térmica até cerca de $300^{\circ} \mathrm{C}$. Não foram observadas diferenças no comportamento térmico entre os clones da série IAC e o RRIM 600. Os clones IAC 500, IAC 501, IAC 502, IAC 503 e IAC 506 são mais promissores para plantações em pequena escala, em virtude de seu crescimento e potencial produtivo.

Termos para indexação: Hevea brasiliensis, espessura de casca, secamento do painel, vigor, produção.

\section{Introduction}

The main selection parameters for Hevea brasiliensis (Willd. ex Adr. de Juss.) Muell. Arg. breeding include: high rubber yield; precocity, i.e., early attainment of tappable girth; and timber yield potential (Mydin et al., 2005; Gonçalves \& Marques, 2008), an aspect that has recently gained significance in determining the worth of rubber clones. Hybridization and clonal selection have resulted in the release of numerous outstanding $H$. brasiliensis clones. The heterogeneous seedling populations produced by hybridization are evaluated in nurseries, and the selected hybrids are then cloned and assessed in a phased manner in small-scale,

Pesq. agropec. bras., Brasília, v.46, n.12, p.1643-1649, dez. 2011 
large-scale and farm trials (Gonçalves \& Marques, 2008; Priyardarshan et al., 2009).

In São Paulo State, Brazil, rubber improvement was initiated in 1963 by the Instituto Agronômico (IAC) with the first hybridization program, which led to the release of the IAC 300 (Gonçalves et al., 2002) and IAC 400 clones (Gonçalves et al., 2007). Currently, field tests on the new IAC 500 series clones are being carried out.

For Hevea, selective hybridization between superior clones, as well as ortet selection (plus tree selection), followed by vegetative multiplication and evaluation, could produce many promising clones. Improved clones, obtained by adopting these two techniques, are used as planting materials since 1958 in São Paulo State (Cunha, 1966).

Attempts were made to extend rubber cultivation to the non-traditional regions of Brazil, where nearly tropical climatic conditions prevail (Camargo et al., 2003). One of these regions is southwestern Brazil, where the continental upland of the region is a South American leaf blight (SALB) escape area (Ortolani et al., 1998; Camargo et al., 2003), and the daily and monthly high rainfall or continuous water excess is not related to high latex production. The crop yield models, described for this continental plateau for soybean (Camargo et al., 1986) and for oranges (Camargo et al., 1995), indicate excessive water as a limiting factor for development and yield.

The objective of this work was to evaluate the performance of 15 clones of the IAC 500 series of H. brasiliensis, developed at IAC, over a 12-year period, in the northwest region of São Paulo State, Brazil.

\section{Materials and Methods}

The experiment was carried out at the Estação Experimental de Votuporanga, in the northwest region of São Paulo State, Brazil $\left(20^{\circ} 25^{\prime} 00^{\prime \prime} \mathrm{S}\right.$ and $49^{\circ} 59^{\prime} 00^{\prime \prime} \mathrm{W}$, at 450-m altitude), in 2000. Mean monthly temperatures varied from 20 to $25^{\circ} \mathrm{C}$, and annual rainfall totals during the experiment ranged from 1,087 to $1,537 \mathrm{~mm}$. Winter drought varied from four to six dry months, with an average water deficiency of $180 \mathrm{~mm}$. The soil of the area is classified as a Argissolo Vermelho Amarelo (Santos et al., 2006), with loamy sand texture and low fertility.
The genetic materials used in the experiment were 15 Hevea genotypes (clones), developed by IAC, and the control RRIM 600, developed by the Rubber Research Institute of Malaysia (RRIM), which were evaluated in a small-scale trial. The clones were budded onto established GT 1 clonal rootstocks in a nursery. One-and-a-half-year-old rootstock seedlings raised in nurseries were used to budgraft the clonal materials. The successful budgrafts were uprooted and planted in plastics bags. The experiment was planted in the field after the first flush of leaves.

The experimental design was a randomized complete block with three replicates, using ten trees per plot with $8.0 \times 2.5 \mathrm{~m}$ spacing. Missing plants were replaced with spares during the first two years after planting to maintain plantation density, but were not scored. One row of the RRIM 600 clone, acquired from a commercial nursery, was planted around the plot. Annual fertilizations consisted of $400 \mathrm{~g}$ per plant of N-P-K (10-10-10), according to Bataglia et al. (2003).

The trees were opened for tapping at the sixth year. Tapping was on half-spiral, with four daily tappings and seven tappings per month, 11 months per year. The following characters were recorded: dry rubber yield ( $\mathrm{g}$ per tree per tapping) over four years; tree girth 11 years after planting; girth increment before and during tapping; thickness and number of latex vessel rows of seven-year virgin bark; percent incidence of wind damage; tapping panel dryness; and major diseases under normal prophylactic conditions for annual latex production.

Attempts were made to record four annual yields after panel opening by the cup coagulation method, on two normal tapping days per month, i.e., by coagulating the latex from individual trees in a collecting cup by adding $2 \%$ acetic acid solution and stirring. The coagulated rubber was pressed into a cylinder, dried for 30 days and then weighed for calculation of dry rubber content.

Tree girth was recorded once a year $120 \mathrm{~cm}$ above bud union with a tailors' tape. The first measurement, at 12 months, consisted of diameters, since the plants were too small to measure girth. Plant diameter was measured $50 \mathrm{~cm}$ above ground level with a slide caliper. This measurement was converted to girth, assuming that the stem was cylindrical. Bark thickness was measured with a Schleiper gauge (Schleiper Paris SA, Paris, France). For recording the number of latex vessel 
rows, bark samples were sectioned in the radial plane and stained with Sudan III; the number of latex vessel rows was counted using a light microscope. Incidence of diseases was assessed by visual observation. Data on dry rubber yield, dry rubber yield depression, girth, bark thickness and latex vessel rows were statistically analyzed.

For the panel, anthracnose, caused by Colletotrichum gloeosporioides (Penz.) Sacc., was evaluated by the severity of the symptoms in the panels, using a gradual grade scale from 1 to 5 , in which: 1, low; 2, below average; 3 , average; 4 , above average; 5 , high. The data were transformed into infection indexes, according to Bajungu (1977).

Thermogravimetry (TG) and derivative thermogravimetry (DTG) of the rubber from the IAC 500 and RRIM 600 clones were carried out using a thermogravimetric analyzer model Q500, (TA Instruments, New Castle, DE, USA). Samples were scanned from 25 to $600^{\circ} \mathrm{C}$, at a heating rate of $10^{\circ} \mathrm{C}$ per min, in an inert atmosphere, using nitrogen. A total of $10 \mathrm{mg}$ of each sample was used for each preparation.

Two methods were used for comparing dry rubber yield: g per tree per tapping and $\mathrm{kg}$ per hectare per year. Each method has its particular value. The first allows for a comparison of the yield potential of the trees, without taking into account differences in the number of trees in relation to tapping. The mean yield is calculated from the yields of all recorded trees under tapping during the year. The second method gives a comparison in which a clone with high yield per tree, but with a low number of trees under tapping, may appear to be of the same productive value as another clone, with a low yield per tree, but a higher number of trees under tapping. To assess the value of a clone, both types of yield records need to be examined together. However, in the early years of tapping, the yield per tree is a better indicator of yield potential than the yield per hectare, due to the wide differences in tappability or tappable stands per hectare among clones at opening (Tan, 1987).

All statistical analyses were performed using the Genes software, Windows version, 2001 (Cruz, 2008).

\section{Results and Discussion}

Annual combined analyses of variance for dry rubber yield and annual girth increment varied among clones and years. This difference indicates good perspectives for the selection of clones. The experimental coefficients of variation were higher for girth increment. However, the low coefficient of variation for dry rubber yield indicates the need for greater accuracy in the field. In addition, the year effect showed significant values for both characters. The effect of the clones $\mathrm{x}$ year interaction was also significant, indicating that these characters were affected by the variation between years.

Mean yield for the first four years, annual mean, percentage control and relative rank are given in Table 1. Yield figures for the first year indicated that $40 \%$ of the clones were superior to the control, with IAC 500 showing the highest yield, followed by IAC 502 and IAC 503.

Mean dry rubber yield varied over the four years of tapping. Clones IAC 500 and IAC 502 showed the highest mean dry rubber yields, which were 38 and $28 \%$ higher than that of the control clone, respectively. Eight clones - IAC 500, IAC 501, IAC 502, IAC 503, IAC 505, IAC 506, IAC 511 and IAC 512 -, were superior to the control in this aspect. Analysis of winter yield depression indicated that most of the clones are significantly superior to the control regarding summer yield.

Girth at the sixth and tenth year, mean girth increment before and during tapping, mean bark thickness and number of latex vessel rows of seven-year virgin bark were separately ranked within the selected clones (Table 2).

The high yielding clones IAC 505, IAC 507 and IAC 512 recorded the highest girths at opening, while clone RRIM 600 showed low girth in all years of evaluation. At the tenth year, IAC 505, IAC 507 and IAC 511 recorded the highest girths, while that of RRIM 600 was 22 to $30 \%$ lower. The lowest girth was found in another high yielding clone, IAC 506. This is in agreement with the observation that high yield is not necessarily associated with high girth increment (Gonçalves \& Marques, 2008). The percentage of tappable trees varied between $25 \%$ (IAC 504) and $100 \%$ (IAC 512) at opening. As mentioned earlier, the trials were opened for tapping at different ages, from five and a half to seven years. Therefore, clones were not uniformly represented in the trial. Consequently, it is necessary to standardize the age assessed in the trial in order to make a fair comparison of the girths among the clones. Mean girths during the first three 
years have been found to be highly correlated with mean the former is preferably used for the assessment of the girths at opening (Gonçalves et al., 2007). For this reason, clones.

Table 1. Dry rubber yield (g per tree per tapping and $\mathrm{kg} \mathrm{ha}^{-1}$ per year) of four years, and rank compared to the percentage control (RRIM 600) of 15 Hevea brasiliensis clones from the IAC 500 series evaluated in a small scale clone trial in the northwest of São Paulo State, Brazil ${ }^{(1)}$.

\begin{tabular}{|c|c|c|c|c|c|c|c|c|c|c|c|c|c|c|c|c|}
\hline \multirow[t]{2}{*}{ Clone } & \multicolumn{3}{|c|}{ First year } & \multicolumn{3}{|c|}{ Second year } & \multicolumn{3}{|c|}{ Third year } & \multicolumn{3}{|c|}{ Fourth year } & \multicolumn{3}{|c|}{ Mean } & \multirow{2}{*}{$\begin{array}{c}\text { Winter yield } \\
\text { depression as } \\
\% \text { of mean yield }\end{array}$} \\
\hline & $\begin{array}{c}\text { g per tree } \\
\text { per tapping }\end{array}$ & Rank & $\begin{array}{l}\mathrm{kg} \mathrm{ha}^{-1} \\
\text { per year }\end{array}$ & $\begin{array}{l}\text { g per tree } \\
\text { per tapping }\end{array}$ & Rank & $\begin{array}{l}\mathrm{kg} \mathrm{ha}^{-1} \\
\text { per year }\end{array}$ & $\begin{array}{c}\text { g per tree } \\
\text { per tapping }\end{array}$ & Rank & $\begin{array}{l}\mathrm{kg} \mathrm{ha}^{-1} \\
\text { per year }\end{array}$ & $\begin{array}{l}\text { g per tree } \\
\text { per tapping }\end{array}$ & Rank & $\begin{array}{l}\mathrm{kg} \mathrm{ha}^{-1} \\
\text { per year }\end{array}$ & $\begin{array}{l}\text { g per tree } \\
\text { per tapping }\end{array}$ & Rank & $\begin{array}{l}\mathrm{kg} \mathrm{ha}^{-1} \\
\text { per year }\end{array}$ & \\
\hline IAC 500 & 46.37 & 1 & 801 & 55.42 & 4 & 1,357 & 87.75 & 1 & 2,527 & 77.71 & 2 & 2,238 & 66.81 & 1 & 1,731 & 1.96 \\
\hline IAC 501 & 37.44 & 8 & 647 & 55.55 & 3 & 1,360 & 64.37 & 7 & 1,854 & 70.01 & 5 & 2,016 & 56.84 & 5 & 1,469 & 29.55 \\
\hline IAC 502 & 44.59 & 2 & 771 & 56.95 & 1 & 1,394 & 77.67 & 2 & 2,237 & 70.28 & 4 & 2,024 & 62.37 & 2 & 1,607 & 22.76 \\
\hline IAC 503 & 43.41 & 3 & 750 & 52.34 & 5 & 1,281 & 75.18 & 3 & 2,165 & 69.89 & 6 & 2,013 & 60.21 & 3 & 1,552 & 19.20 \\
\hline IAC 504 & 33.15 & 12 & 573 & 42.57 & 12 & 1,042 & 39.00 & 16 & 1,123 & 69.38 & 7 & 1,998 & 46.03 & 13 & 1,184 & 23.10 \\
\hline IAC 505 & 41.11 & 4 & 710 & 45.07 & 8 & 1,103 & 55.94 & 8 & 1,611 & 57.99 & 11 & 1,670 & 50.03 & 8 & 1,274 & 22.71 \\
\hline IAC 506 & 36.71 & 9 & 634 & 56.33 & 2 & 1,379 & 72.33 & 4 & 2,083 & 65.04 & 8 & 1,873 & 57.60 & 4 & 1,492 & 19.92 \\
\hline IAC 507 & 39.65 & 6 & 685 & 44.17 & 10 & 1,081 & 50.61 & 14 & 1,458 & 59.34 & 10 & 1,709 & 48.44 & 11 & 1,233 & 18.17 \\
\hline IAC 508 & 40.42 & 5 & 698 & 41.00 & 15 & 1,004 & 52.13 & 12 & 1,501 & 40.73 & 16 & 1,432 & 43.57 & 15 & 1,159 & 20.12 \\
\hline IAC 509 & 37.44 & 8 & 645 & 44.47 & 9 & 1,089 & 52.55 & 11 & 1,513 & 53.35 & 14 & 1,536 & 46.95 & 12 & 1,196 & 25.82 \\
\hline IAC 510 & 34.09 & 10 & 589 & 45.79 & 7 & 1,121 & 51.71 & 13 & 1,489 & 50.25 & 15 & 1,447 & 45.46 & 14 & 1,162 & 18.00 \\
\hline IAC 511 & 33.86 & 11 & 585 & 46.41 & 6 & 1,136 & 52.67 & 10 & 1,517 & 72.71 & 3 & 2,094 & 51.41 & 7 & 1,333 & 10.00 \\
\hline IAC 512 & 32.64 & 14 & 564 & 43.73 & 11 & 1,070 & 69.33 & 5 & 1,997 & 79.21 & 1 & 2,281 & 56.23 & 6 & 1,478 & 19.95 \\
\hline IAC 513 & 30.67 & 15 & 530 & 41.24 & 14 & 1,009 & 66.13 & 6 & 1,905 & 55.98 & 12 & 1,613 & 48.51 & 10 & 1,264 & 5.82 \\
\hline IAC 514 & 32.71 & 13 & 565 & 35.00 & 16 & 917 & 44.40 & 15 & 1,279 & 54.08 & 13 & 1,557 & 41.55 & 16 & 1,080 & 23.50 \\
\hline RRIM 600 & 37.86 & 7 & 631 & 42.35 & 13 & 1,068 & 53.60 & 9 & 1,544 & 61.01 & 9 & 1,757 & 48.71 & 9 & 1,250 & 30.55 \\
\hline Mean & 37.63 & & 649 & 46.77 & & 1,151 & 60.34 & & 1,738 & 62.94 & & 1,829 & 51.92 & & 1,341 & \\
\hline SE & 1.17 & & 20.22 & 1.64 & & 38.08 & 3.34 & & 96.18 & 2.65 & & 68.74 & 1.82 & & 47.20 & \\
\hline CV $(\%)$ & 12.42 & & 12.46 & 13.99 & & 13.23 & 22.13 & & 22.14 & 16.87 & & 15.03 & 13.98 & & 14.07 & \\
\hline
\end{tabular}

(1) In the first, second, third and fourth years of tapping, 240, 340, 380 and 400 trees per hectare were considered, respectively. Tapping system: $1 / 2 \mathrm{~S} d / 45 \mathrm{~d} / 7.11 \mathrm{~m} / \mathrm{y} . \mathrm{ET}$ $2.5 \% \mathrm{~Pa} 2(1) \cdot 10 / \mathrm{y}$.

Table 2. Secondary characters of 15 Hevea brasiliensis clones from the IAC 500 series compared to the control (RRIM 600) in a small scale clone trial ir the northwest of São Paulo State, Brazil.

\begin{tabular}{|c|c|c|c|c|c|c|c|c|c|c|c|c|c|c|}
\hline \multirow[t]{2}{*}{ Clone } & \multicolumn{4}{|c|}{ Girth $(\mathrm{cm})$} & \multicolumn{4}{|c|}{ Average annual girth increment $(\mathrm{cm})$} & \multicolumn{2}{|c|}{ Tappable trees $(\%)$} & \multicolumn{2}{|c|}{ Virgin bark $(\mathrm{mm})$} & \multicolumn{2}{|c|}{ Latex vessel rows } \\
\hline & $\begin{array}{l}\text { Opening } \\
\left(6^{\text {th }} \text { year }\right)\end{array}$ & Rank & $\begin{array}{l}10^{\text {th }} \\
\text { year }\end{array}$ & Rank & $\begin{array}{l}\text { Opening } \\
\left(6^{\text {th }} \text { year }\right)\end{array}$ & Rank & $\begin{array}{l}10^{\text {th }} \\
\text { year }\end{array}$ & Rank & $\begin{array}{l}\text { Opening } \\
\left(6^{\text {th }} \text { year }\right)\end{array}$ & Rank & $\begin{array}{l}\text { Opening } \\
\left(6^{\text {th }} \text { year }\right)\end{array}$ & Rank & $\begin{array}{l}\text { Opening } \\
\left(6^{\text {th }} \text { year }\right)\end{array}$ & Rank \\
\hline IAC 500 & 46.92 & 7 & 56.00 & 10 & 7.10 & 12 & 2.11 & 10 & 75 & 3 & 6.19 & 2 & 14.30 & 2 \\
\hline IAC 501 & 45.13 & 9 & 53.42 & 11 & 7.52 & 7 & 1.98 & 13 & 67 & 5 & 4.50 & 11 & 9.18 & 14 \\
\hline IAC 502 & 48.86 & 5 & 60.56 & 5 & 8.14 & 5 & 2.57 & 4 & 72 & 4 & 5.67 & 4 & 11.19 & 7 \\
\hline IAC 503 & 44.64 & 11 & 57.83 & 7 & 7.44 & 9 & 2.92 & 3 & 61 & 6 & 6.23 & 1 & 12.62 & 3 \\
\hline IAC 504 & 38.73 & 16 & 52.75 & 12 & 6.41 & 14 & 3.11 & 2 & 25 & 11 & - & - & - & - \\
\hline IAC 505 & 58.24 & 1 & 69.71 & 1 & 9.71 & 1 & 2.40 & 6 & 89 & 2 & 5.21 & 6 & 10.56 & 10 \\
\hline IAC 506 & 38.39 & 15 & 47.90 & 16 & 6.40 & 15 & 2.05 & 11 & 25 & 11 & - & - & - & - \\
\hline IAC 507 & 56.17 & 2 & 65.67 & 2 & 9.36 & 2 & 2.25 & 7 & 89 & 2 & 5.08 & 9 & 10.71 & 8 \\
\hline IAC 508 & 43.15 & 12 & 51.82 & 14 & 7.19 & 10 & 1.85 & 15 & 42 & 8 & 4.26 & 13 & 9.67 & 13 \\
\hline IAC 509 & 41.22 & 13 & 50.83 & 15 & 6.87 & 13 & 2.13 & 9 & 28 & 10 & 4.43 & 12 & 10.10 & 12 \\
\hline IAC 510 & 44.82 & 10 & 56.80 & 9 & 7.47 & 8 & 3.76 & 1 & 56 & 7 & 6.01 & 3 & 12.31 & 4 \\
\hline IAC 511 & 51.82 & 4 & 62.80 & 3 & 8.64 & 4 & 2.50 & 5 & 72 & 4 & 5.16 & 7 & 15.73 & 1 \\
\hline IAC 512 & 53.22 & 3 & 61.50 & 4 & 8.87 & 3 & 2.15 & 8 & 100 & 1 & 5.39 & 5 & 11.22 & 6 \\
\hline IAC 513 & 46.33 & 8 & 57.83 & 6 & 7.72 & 6 & 0.72 & 16 & 67 & 5 & 5.09 & 8 & 10.29 & 11 \\
\hline IAC 514 & 47.29 & 6 & 57.50 & 8 & 7.44 & 9 & 1.99 & 12 & 75 & 3 & 4.19 & 14 & 10.60 & 9 \\
\hline RRIM 600 & 41.10 & 14 & 52.57 & 13 & 7.12 & 11 & 1.97 & 14 & 38 & 9 & 5.02 & 10 & 11.55 & 5 \\
\hline Mean & 46.63 & & 57.22 & & 7.71 & & 2.28 & & 61.31 & & 5.17 & & 11.43 & \\
\hline $\mathrm{SE}$ & 1.38 & & 1.37 & & 0.23 & & 0.15 & & 557 & & 0.16 & & 0.43 & \\
\hline CV (\%) & 12.55 & & 10.12 & & 12.73 & & 28.77 & & 38.57 & & 13.12 & & 15.77 & \\
\hline
\end{tabular}


Mean girth increment per year before tapping ranged from a minimum of $6.40 \mathrm{~cm}$ (IAC 506) to a maximum of $9.71 \mathrm{~cm}$ (IAC 505). Clone RRIM 600 recorded mean girth increments of $7.12 \mathrm{~cm}$ before tapping. The rate of girth increment during the tapping period, over three years, also varied among the clones. Clones IAC 510 and IAC 504 showed the highest girth increment, followed by IAC 503, IAC 502 and IAC 511, when compared to the control clone RRIM 600. Girthing rate on tapping is important when considering future yield and wind damage (Priyadarshan et al., 2009). In addition, good girthing in tapping, according to Tan (1987), sustains yield and reduces wind damage losses through trunk snap.

All the clones were found to be similar to the control for bark thickness of the six-year virgin bark. IAC 503 showed the highest bark thickness, while IAC 514 had the lowest (Table 2). Gonçalves \& Marques (2008) reported that thick bark is very important because it minimizes wounding incidence, which is known to affect productivity on later panels.

At opening, clones IAC 500, IAC 503, IAC 510 and IAC 511 had a higher number of latex vessel rows than the control, while ten clones had a smaller number. The number of vessel rings, according to Henon \& Nicolas (1989), appeared to be the parameter that most influences latex production. Its correlation with yield, established by the Hamaker Morris-Mann test for early tapping of seedlings, is good $(\mathrm{r}=0.64)$. Tixier (1953) examined the same relation in ten six-year-old clones and obtained a correlation (r) of 0.75 . However, while assessing AVROS 226, a low-yielding clone with many latex vessel rings, the author also took into account other criteria, such as girth and bark thickness, in the evaluation of rubber yield.

Only trees which were lost through trunk snap, uprooting or stumped above $2 \mathrm{~m}$ were considered losses due to wind damage. The incidence of wind damage up to the tenth year of growth is recorded in Table 3 . All the clones were affected by wind, with varying incidence from $1.03 \%$ (IAC 500) to $9.32 \%$ (IAC 509). The control clone RRIM 600 recorded $10.15 \%$ wind damage. Tolerance to wind minimizes losses, ensuring a good tapping stand throughout the economic life of the crop, and may be associated with branching habit, tree height, long latex flow or low plugging index - leading to an adverse partition and, therefore, imbalance between crown and trunk components -, and wood property (Priyadarshan et al., 2009).
To assess tapping panel dryness, only genuine cases of dry trees were considered; trees that became dry as a consequence of wind damage were excluded. Dry tree incidence was recorded over four years of tapping (Table 3). All the trial trees were uniformly tapped on $\mathrm{S} / 2 \mathrm{~d} / 4$. However, clonal susceptibility to dryness can be better assessed only after several years of tapping (Sultan, 1973). Incidence of tapping panel dryness was observed in almost all the evaluated clones. IAC 507 was the most susceptible, followed by IAC 503 and IAC 505.

All clones were found to be more or less susceptible to anthracnose leaf and panel disease, caused by C. gloeosporioides, of which five - IAC 500, IAC 505, IAC 506, IAC 510 and IAC 514-showed comparatively low incidence under normal prophylactic conditions (Table 3). Other clones were severely affected by this malady. Anthracnose panel disease incidence also affected all clones with varying intensity, from high to low. Based on the present study, four clones (IAC 506, IAC 510, IAC 512 and IAC 513) were found to be superior regarding anthracnose panel disease. This malady was detected in tapping panels of clone RRIM 600 by Silveira et al. (1992), in which genetic studies were initiated. This disease has since assumed

Table 3. Percentage of wind damage, tapping panel dryness and incidence of anthracnose leaf and panel disease in 15 Hevea brasiliensis clones from the IAC 500 series in a small scale trialw in the northwest of São Paulo State, Brazil.

\begin{tabular}{|c|c|c|c|c|}
\hline \multirow[t]{2}{*}{ Clone } & \multirow{2}{*}{$\begin{array}{c}\text { Wind } \\
\text { damage }\end{array}$} & \multirow{2}{*}{$\begin{array}{l}\text { Tapping panel } \\
\text { dryness }\end{array}$} & \multicolumn{2}{|c|}{$\begin{array}{c}\text { Anthracnose } \\
\text { incidence }\end{array}$} \\
\hline & & & Leaf & Panel \\
\hline IAC 500 & 1.03 & 2.82 & Below average & Below average \\
\hline IAC 501 & 4.22 & 3.48 & Below average & Above average \\
\hline IAC 502 & 3.44 & 1.29 & Low & Above average \\
\hline IAC 503 & 6.20 & 3.65 & Low & Above average \\
\hline IAC 504 & 3.31 & 3.43 & Low & Above average \\
\hline IAC 505 & 2.10 & 3.52 & Low & Below average \\
\hline IAC 506 & 2.10 & 2.66 & Low & Low \\
\hline IAC 507 & 5.93 & 3.67 & High & Above average \\
\hline IAC 508 & 4.67 & 2.54 & High & Above average \\
\hline IAC 509 & 9.32 & 2.57 & Average & Average \\
\hline IAC 510 & 2.28 & 2.38 & Below average & Low \\
\hline IAC 511 & 4.61 & 0.81 & Average & Average \\
\hline IAC 512 & 1.22 & 1.61 & Average & Low \\
\hline IAC 513 & 2.18 & 2.83 & Average & Low \\
\hline IAC 514 & 3.12 & 1.61 & Below average & Below average \\
\hline RRIM 600 & 10.15 & 2.81 & Average & Average \\
\hline
\end{tabular}


epidemic proportions in many rubber plantations in São Paulo State (Furtado, 2008).

One of the most widely accepted methods for studying the thermal properties of polymeric materials is thermogravimetry. Thermogravimetric data provides information on thermal breakdown, mass loss of the material in different stages, threshold temperature, and the nature and the extent of the degradation of the material (Asaletha et al., 1998). Typical TG/ DTG curves obtained for raw natural rubber from the IAC 500 series and the RRIM 600 clones in inert atmosphere (Figure 1) showed that the TG curve has only one large plateau and that the DTG curve has one degradation peak. Therefore, the thermal degradation of the raw natural rubber of the IAC clones is a one-stage reaction. The temperature of the initial degradation
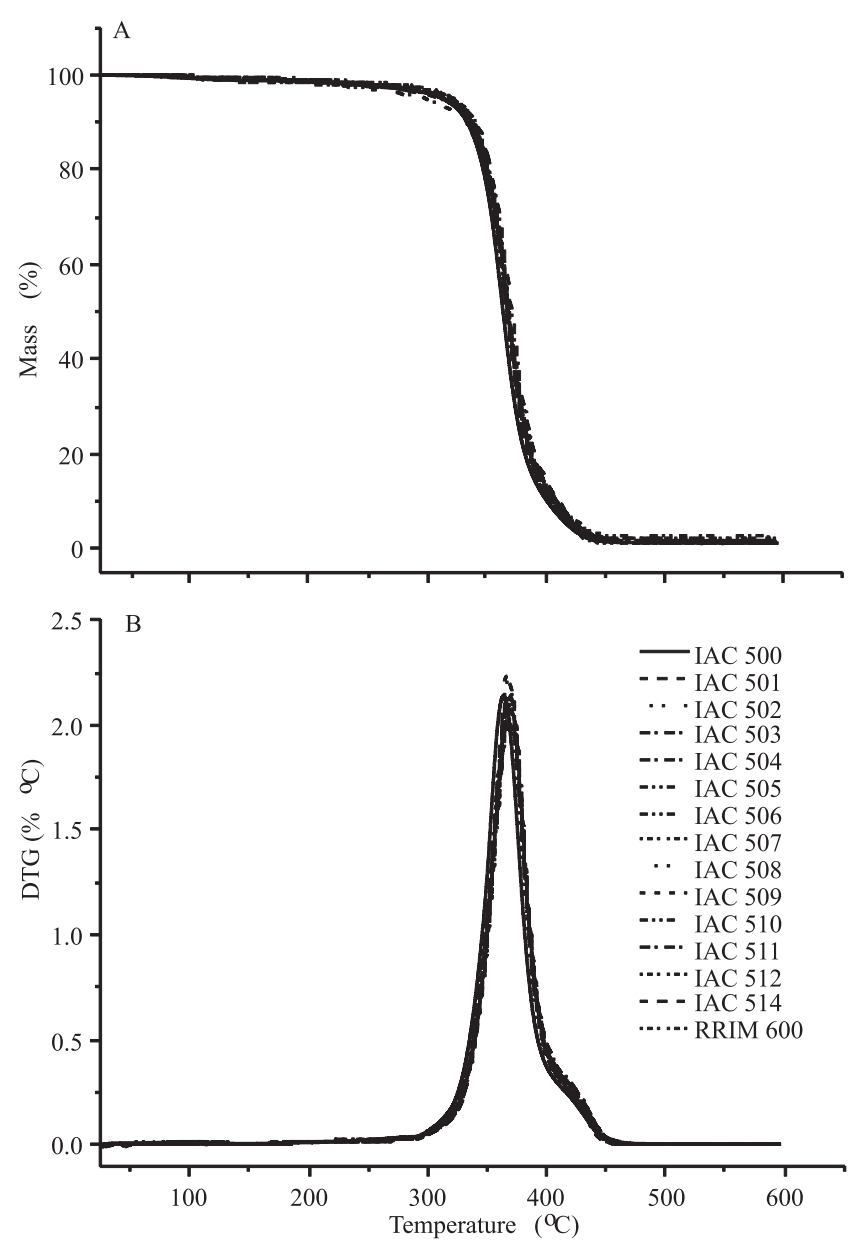

Figure 1. Thermogravimetry $\mathrm{TG}$ (A) and derivative thermogravimetry DTG (B) curves of the rubber from the IAC 500 series and RRIM 600 Hevea brasiliensis clones in inert atmosphere. process onset $\left(\mathrm{T}_{\mathrm{i}}\right)$ is around $300^{\circ} \mathrm{C}$, and at $600^{\circ} \mathrm{C}$ the residue content was insignificant for all clones. This indicates that few impurities were added during the latex extraction process in the plantation. A small shoulder can be observed at approximately $430^{\circ} \mathrm{C}$, attributed to the slow decomposition of the most entangled or cross linked chains (Rippel, 2005). The temperature at which $50 \%$ decomposition occurs is generally considered as an index of thermal stability (Menon et al., 1996). The results obtained showed that, for the rubber from IAC clones, this temperature is about $370^{\circ} \mathrm{C}$, indicating good thermal stability. The TG and DTG curves for all clones are almost identical, which indicates that the thermal decomposition mechanism is the same. There were no significant differences in thermal behavior among the IAC 500 and RRIM 600 clones.

\section{Conclusions}

1. Based on growth and yield potential, IAC 500, IAC 501, IAC 502, IAC 503 and IAC 506 are the more promising Hevea brasiliensis clones recommended for small-scale plantations.

2. In relation to vigor, IAC 505, IAC 507, IAC 511 and IAC 512 are very precocious clones, and the opening of the panel is possible at five years and six months of age, with similar yield to the control clone RRIM 600.

3. The clones IAC 505, IAC 507, IAC 511 and IAC 512 are recommended for planting due to their yield and fast growth characteristics, and can be used as parents for improvement programs in future breeding and selection work.

\section{Acknowledgments}

To Fundação de Amparo à Pesquisa do Estado de São Paulo, to Conselho Nacional de Desenvolvimento Científico e Tecnológico and to Secretaria de Agricultura e Abastecimento do Estado de São Paulo, for support.

\section{References}

ASALETHA, R.; KUMARAN, M.; THOMAS, S. Thermal behaviour of natural rubber/polystyrene blends: thermogravimetric and differential scanning calorimetric analysis. Polymer Degradation and Stability, v.61, p.431-439, 1998.

BAJUNGU, H.E. Avaliação de perdas de colheitas causadas pelos patógenos. Piracicaba: ESALQ, 1977. 87p. 
BATAGLIA, O.C.; SANTOS, W.R. dos; GONÇALVES, P. de S.; SEGNINI JR., I.; CARDOSO, M. Efeito da adubação NPK sobre o período de imaturidade da seringueira. Bragantia, v.58, p.363374, 1999.

CAMARGO, A.P. de; MARIN, F.R.; CAMARGO, M.B.O. de. Zoneamento climático da heveicultura no Brasil. Campinas: Embrapa Monitoramento por Satélite, 2003. 19p. (Embrapa Monitoramento por Satélite. Documentos, 24).

CAMARGO, M.B.P. de; BRUNINI, O.; MIRANDA, M.A.C. de. Modelo agrometeorológico para estimativa da produtividade para a cultura da soja no Estado de São Paulo. Bragantia, v.45, p.279-292, 1986.

CAMARGO, M.B.P. de; PEDRO JÚNIOR, M.J.; ORTOLANI, A.A.; ROSA, S.M. Desenvolvimento e teste de modelos agrometeorológicos de estimativa da produtividade de laranjais no Estado de São Paulo. In: CONGRESSO BRASILEIRO DE AGrometeorologiA, 9., 1995, Campina Grande. Anais. Campina Grande: Sociedade Brasileira de Agrometeorologia, 1995. p.412-414.

CRUZ, C.D. Programa Genes: aplicativo computacional em genética e estatística. Viçosa: UFV, 2008. 278p.

CUNHA, J.F. da. A seringueira (Hevea brasiliensis Muell.-Arg.) no Vale do Paraíba. Bragantia, v.25, p.129-144, 1966.

FURTADO, E.L. Doenças das folhas e do caule da seringueira. In: ALVARENGA, A. de P.; CARMO, C.A.F. de S. do. (Coord.). Seringueira. Viçosa: EPAMIG, 2008. p.499-534.

GONÇALVES, P. de S.; MARQUES, J.R.B. Melhoramento genético da seringueira: passado, presente e futuro. In: ALVARENGA, A. de P.; CARMO, C.A.F. de S. do. (Coord.). Seringueira. Viçosa: EPAMIG, 2008. p.399-534.

GONÇALVES, P. de S.; MARTINS, A.L.M.; FURTADO, E.L.; SAMBUGARO, R.; OTTATI, E.L.; ORTOLANI, A.A.; GODOY JUNIOR, G. Desempenho de clones de seringueira da série IAC 300 na região do planalto de São Paulo. Pesquisa Agropecuária Brasileira, v.37, p.131-138, 2002.

GONÇALVES, P. de S.; SILVA, M. de A.; AGUIAR, A.T. da E.; MARTINS, M.A.; SCALOPPI JUNIOR, E.J.; GOUVÊA, L.R.L. Performance of new Hevea clones from IAC 400 series. Scientia Agricola, v.64, p.241-248, 2007.

HENON, J.M.; NICOLAS, D. Relation between anatomical organizations of the latex yield: search for early criteria. In:
D’AUZAC, J.; JACOB, J.-L.; CHRESTIN, H. (Ed.). Physiology of rubber tree latex. Florida: CRC, 1989. p.31-50.

MENON, A.R.R.; PILLAI, C.K.S.; NANDO, G.B. Thermal degradation characteristics of natural rubber vulcanizates modified with phosphorylated cashew nut shell liquid. Polymer Degradation and Stability, v.52, p.265-271, 1996.

MYDIN, K.K.; JOHN, A.; NAZEER, M.A.; PREM, E.E.; THOMAS, V.; SARASWATHYAMMA, C.K. Promising Hevea brasiliensis clones evolved by ortet selection with emphasis on latex - timber traits and response to stimulation. Journal of Plantation Crops, v.33, p.18-28, 2005.

ORTOLANI, A.A.; SENTELHAS, P.C.; CAMARGO, M.B.P.; PEZZOPANE, J.E.M.; GONÇALVES, P. de S. Agrometeorological model for seasonal rubber tree yield. Indian Journal of Natural Rubber Research, v.11, p.8-14, 1998.

PRIYADARSHAN, P.M.; GONÇALVES, P. de S.; OMOKHAFE, K.O. Breeding Hevea rubber. In: JAIN, S.M.; PRIYADARSHAN, P.M. (Ed.). Breeding plantation tree crops: tropical species. New York: Springer, 2009. p.469-524.

RIPPEL, M.M. Caracterização microestrutural de filmes e partículas de látex de borracha natural. 2005. 319p. Tese (Doutorado) - Universidade Estadual de Campinas, Campinas.

SANTOS, H.G. dos; JACOMINE, P.K.T.; ANJOS, L.H.C. dos; OLIVEIRA, V.A. de; OLIVEIRA, J.B. de; COELHO, M.R.; LUMBRERAS, J.F.; CUNHA, T.J.F. (Ed.). Sistema brasileiro de classificação de solos. 2.ed. Rio de Janeiro: Embrapa Solos, 2006. $306 \mathrm{p}$.

SILVEIRA, A.P. da; FURTADO, E.L.; LOPES, M.E.B.M. Antracnose: nova doença do painel de sangria de seringueira. Summa Phytopathologica, v.18, p.195-200, 1992.

SULTAN, M.O. Assessment of some new clones for the future. In: PRIM PLANTERS CONFERENCE, 1973, Kuala Lumpur. Proceedings. Kuala Lumpur: Rubber Research Institute of Malaysia, 1973. p.281-299.

TAN, H. Strategies in rubber tree breeding. In: ABBOTT, J.; ATKIN R.K. (Ed.). Improving vegetatively propagated crops. London: Academic, 1987. p.27-62.

TIXIER, P. Examen anatomique des écorces d'Hevea. Paris : Institut de Recherches sur le Caoutchouc en Indochine, 1953. 112p. (Annual report).

Received on July 27, 2011 and accepted on November 30, 2011 